trees standing around each colony of woodpeckers living on their land.

The new secretary also announced a plan to end longstanding turf wars among various interior department agencies by bringing staff scientists together under the umbrella of a National Biological Survey (similar to the US Geological Survey founded a century ago). The survey, which is likely to become reality this fall if, as expected, Congress passes the necessary funds (see page 751), is designed to separate science from research management so that "we can elevate the credibility of science itself", Babbitt has said.

These are both good moves. But Babbitt showed his mettle (and President Bill Clinton's capacity for deviousness) most demonstrably two weeks ago when he announced higher fees for ranchers who graze their herds on public land (see Nature 364, 659; 1993). Although the increase from $\$ 1.86$ a month per 'animal unit' to $\$ 4.28$ a month is likely to be reduced as the Babbitt plan wends its way through a public rule-making process, its symbolic importance cannot be overstated. An increase in grazing fees was originally in Clinton's economic package, the first of many sound measures the president traded for key congressional votes. But within days of the passage of the fee-free package, the idea that ranchers should pay closer to the market rate for US rangeland forcefully reared its head in the form of Babbitt's proposal, which does not require the blessing of the Senate or the House of Representatives.

This week in Alaska, Babbitt helped end a three-day protest by promising fishermen more help in recovering from the 1989 Exxon Valdez oil spill. The fishermen, who had blocked 60 oil tankers from reaching the Trans-Alaskan pipeline, attribute the recent death of salmon and herring to the spill, which dumped nearly 11 million gallons of crude oil into fishing waters. Babbitt ended the protest by promising to urge Exxon officials to negotiate settlements with the fishermen and to promote aid and protection for fish hatcheries and spawning streams.

Next on the Interior Secretary's agenda are wetlands policy and higher user fees on mining, timber and water rights to federal lands. His purpose is not to put ranchers or miners out of work but rather is to strike a balance between their needs and the need to preserve ecosystems by requiring users to take new (and more costly) steps to preserve the public lands from which they profit. Babbitt has the right ideas.

\section{Pfizer donates drugs}

\section{A pharmaceutical company's public relations policy is} also good for public health

IN a move aimed, no doubt, at the Clinton Administration, which has made US pharmaceutical companies out to be the villains in its health care reform plan, Pfizer Inc. of New York has struck a powerful blow. Hillary Rodham Clinton, in speeches throughout the United States, has attacked the cost of drugs as one of the principal factors driving the US health care bill into the stratosphere. Not surprisingly, the nation's large pharmaceutical companies, which are not only profitable but also highly successful in the international market, argue that the Mrs Clinton is wrong - that the price of drugs reflects the high costs of research and development, not greed.

Now Pfizer has decided to add another arrow to the industry's response to the Clintons. The company has announced that through a new programme charmingly called "Sharing the Care" it will donate to the poor and homeless all 11 of the drugs it makes that are not reproduced by other companies. "Through community, migrant, and homeless health centres in all 50 states [Pfizer] will provide singlesource pharmaceuticals at no charge to patients who live at or below the poverty line", says a company spokesman.

Among the free Pfizer drugs are some of the most medically important: Procardia XL, a calcium channel blocker for the treatment of hypertension, which is widespread among the poor; Diflucan, an anti-fungal agent useful in the treatment of patients whose immune systems have been compromised by AIDS, cancer or organ transplantation; and Glucotrol, a once-a-day drug to lower glucose in diabetics another widespread problem among the population Pfizer is promising to help.

"Sharing the Care" is an expansion of charitable programmes already run by Pfizer and other drug companies that donate certain drugs to health centres for the poor. From a public relations point of view, it is an expansion likely to meet with approval from the Clintons' health care advisers, but it is unlikely to change their overall view of the pharmaceutical industry as a force that drives up costs. But, beyond that, it is sure to strike a positive chord with physicians and nurses ministering to those in desperate need of these drugs. In this case, what is good for Pfizer is also good for medicine.

\section{Only in California}

A school board in the town of Vista, California, has ordered the teaching of creationism in public schools.

The teachers are against it. So are many parents. And scientists in California are duly offended by a local decision that violates state education policy. Nonetheless, by a vote of 3:2, members of the 'Christian Right' in Vista voted that the school curriculum should include the teaching of crcationism in history, social science, literature or science courses "at appropriate times". That apparently means any time that mention is made of divine creation or the ultimate source or purpose of life on this planet.

The temptation to rail against creationism, marshalling all of Darwin and the scientific literature of palaeobiology in defence of evolution, is strong but most likely futile. Some matters are not susceptible to resolution by reasoned argument and this (poor Darwin) is one of them. There will be lawsuits to overturn the Vista creationists, based on arguments that they are illegally promoting a single religion. Who knows, the good guys may win. But at least one can say it happened only in California. 